\title{
Impact of Mobile advertising on consumer attitudes in Algeria: case study of Ooredoo
}

\author{
Amina Merabet ${ }^{\mathrm{a}^{*}}$, Abderrezzak Benhabib ${ }^{\mathrm{b}}$ and Abderrezzak Merabet ${ }^{\mathrm{c}}$
}

${ }^{a}$ Lecturer, Tlemcen university, Algeria, BP: 226 Tlemcen Algeria

${ }^{b}$ Professor, Tlemcen university, Algeria, BP: 226 Tlemcen Algeria

${ }^{c}$ Student, Tlemcen university, Algeria, BP: 226 Tlemcen Algeria

\section{CH R O N I C L E}

Article history:

Received: June 1, 2016

Received in revised format: No-

vember 16, 2016

Accepted: December 22, 2016

Available online:

December 22, 2016

Keywords:

Mobile advertising

Attitude towards mobile advertis-

ing

Brand attitude

Purchase intention

\section{A B S T R A C T}

Mobile advertising is a perfect tool to build a relationship based on proximity between brand and consumer. It is tactile, interactive, and personalized. As few studies have focused on this concept, particularly in the Algerian context, we aim in this research to show the role of mobile advertising on consumer attitudes. After a literature review, an empirical study is conducted among150 students in Tlemcen city. Results, using regression analysis, show that attitude towards mobile advertising had no influence on the attitude towards brand and purchase intention.

(C) 2017 Growing Science Ltd. All rights reserved.

\section{Introduction}

Today Smartphones have penetrated every daily life aspects of Algerians. Indeed, they have reinvented the mobile phone by allowing multiple uses. Advertisers and practitioners specializing in mobile marketing have understood the opportunity offered by these new technologies that help consumers receive personalized and contextualized ads on diverse mobile media. However, if the first effectiveness results of mobile marketing campaigns seem quite encouraging, some studies exhibit lower efficiency of mobile advertising through some mediator variables in advertising effectiveness, particularly as attitude toward mobile advertising. In Algeria, few studies have focused on the influence of mobile advertising on consumer attitudes. Consequently, this study attempts to clarify how mobile advertising influences the attitudes of Algerian consumers. Thus, our objectives are twofold: First, we try to summarize the current state of knowledge on mobile advertising and second, we test causal relationship between mobile advertising and Algerian consumer attitudes.

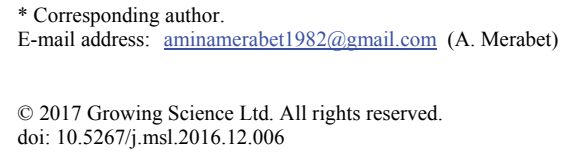




\section{Literature review}

\subsection{Definition of advertising}

Advertising is the favorite instrument of communication. It is "a nonpersonal communication of information usually paid for and usually persuasive in nature about products, services or ideas by identified sponsors through the various media" (Bovee \& Arens, 1994). According to Krugman (1975), advertising success depends on three elements, namely: information, rational stimulus and intensity. Good advertising must have at least one of these elements. Advertising plays a very important role to develop a products or services. On the one hand, it informs customers of the existence of a new product on the market and helps them to find the best products. Second, it increases business sales, changes attitudes and behavior of consumers towards a product. In addition, it strengthens firm credibility.

\subsection{Definition of mobile marketing}

Many definitions exist of mobile marketing. According to Scharl et al. (2005), mobile marketing involves the use of a wireless medium to provide consumers a personalized information that promotes products, services or ideas and thus brings benefits to all stakeholders. According to the Mobile Marketing Association (MMA) (2009), mobile marketing "is a set of practices that enables organizations to communicate and engage with their audience in an interactive and relevant manner through and with any mobile device or network."

This latter definition includes all aspects of mobile marketing. First, the concept of "practice" includes all the marketing processes and activities such as promotions, relationship management, CRM, customer services, loyalty, social marketing. Second, the concept of "engagement" in turn, implies a junction in communication and a social interaction between firms and consumers.

\subsection{Definition of mobile advertising}

According to Li (2004), "Mobile advertising refers to any communication about products, services and ideas that involves the use of mobile devices for promotional purposes". This definition includes not only telephony terminal but also all mobile devices. Although mobile device are different, they have in common the ability to contact consumers in personalized manner wherever they are. Advertisers use more and more the mobile communication medium because it is:

- Powerful: (high mobile penetration rate),

- Personal: mobile is the ideal communication tool One to One,

- Relevant: the mobile allows very precise targeting of marketing campaigns,

- Low cost.

\subsection{Attitude}

Understanding consumer behavior is not easy as it is a key factor in the development of business strategies. Among most of the different consumer behavior models developed up to now, attitude is the variable that retain most attention. Attitude is a key factor in the study of consumer behavior because it is one of the main elements that influence consumer behavior as well as purchase intention.

Since the 20s, researchers have been interested in the concept of attitude that was thought off as the basis of all behavior (Allport, 1935; Campbell, 1963; Doob, 1947). Allport (1935) defines it as " $a$ mental and neural state of readiness, organized through experience, exerting a directive and dynamic influence upon the individual's response to all objects and situations with which it is related". For Kotler et al. (2006), "an attitude sums up the feedback (positive or negative), emotional reactions and predispositions toward an object or idea". This means that attitudes enable an individual to establish 
consistent behavior with respect to a class of similar objects. All these definitions highlight the characteristics of consumer attitude as:

- An attitude is built and results from the evaluations of experiences, An attitude is durable:

- The attitude is based on a set of predispositions that can be favorable or unfavorable to an object or class of objects.

Baker and Churchill (1977) consider that the structure of Attitudes can be described in terms of three components: cognitive (beliefs), affective (feelings) and conative (behavior).

\subsection{The influence of m-advertising on consumer attitudes}

Starting from the idea that $\mathrm{m}$-advertising is a form of advertising, persuasive advertising models can thenceforth be applied. Several authors have attempted to explain the effectiveness of persuasive advertising from the early theories of persuasion based on the hierarchy of effects to the more recent Elaboration Likelihood Model (ELM) (Petty \& Cacioppo, 1981, 1986), and other extension works (Grossbart et al., 1986). In Algeria, also some researchers have tried to explain this phenomenon (Merabet \& Benhabib, 2012, 2014). Furthermore, other studies in the field of mobile advertising are based on the Technology Acceptance Model (TAM) of Davis (1986) by considering mobile advertising as an innovation. This model has been widely used to predict buying intentions (Hoffman \& Novak 1996; Yang, 2005).

\section{The conceptual model}

\subsection{Variables}

\subsubsection{The attitude towards the brand (Ab)}

The previous definitions could be extend to the brand or ad. Howard (1989) defines attitude towards a brand as "the degree of satisfying the needs the consumer thinks this brand may provide". It represents all the assessments made by the consumer on the ability of different brands or products to satisfy needs (Assael, 1984).

\subsubsection{The attitude toward mobile advertising (Aad)}

The attitude toward advertising has been recognized as a central element in the advertising persuasion process. According to Lutz (1985), attitude toward advertising is "a predisposition to respond favorably or unfavorably to a particular advertisement during a particular exposure". For Derbaix (1995), In general, the Aad is a personal and global assessment of an advertising stimulus-related to an exposure situation.

\subsubsection{The purchase intention (Purchase intent) (PI)}

The purchase intention is a very complex concept. Some researchers consider it as a component of the attitude that is on the conative dimension (Greenwald 1968; Kothandapani 1971; Ostrom, 1969), others consider it as an independent variable (Bagozzi, 1981). According to Duhaime et al. (1996), purchase intention is a step of the decision-making process where the consumer expresses its preference for a product based on its experience, beliefs and attitudes.

\subsection{Hypotheses}

Several researchers have shown the positive influence of the attitude toward the ad on the attitude toward the brand and purchase intention. Therefore, we can formulate the following hypotheses: 
$\mathrm{H}_{1}$ : There is a causal link between consumer attitudes towards mobile advertising in general and their attitude towards a brand.

$\mathrm{H}_{2}$ : There is a causal link between consumer attitudes towards mobile advertising in general and their buying intentions.

On the basis of the seminal work of Fishbein and Ajzen (2011), which assumes that in general, attitudes would lead to intentions which, subsequently, would lead to actual behavior, many researchers have been interested in the link between consumer attitudes and intentions of future behavior (e.g., Oliver, 1980; Berger \& Alwitt, 1996). According to their work, we shall check these links and therefore formulate the following hypothesis:

$\mathrm{H}_{3}$ : There is a causal link between consumer attitudes toward a brand and their intentions for future behavior toward that brand.

The above hypotheses can be illustrated in our research framework shown in Fig. 1 as follows,

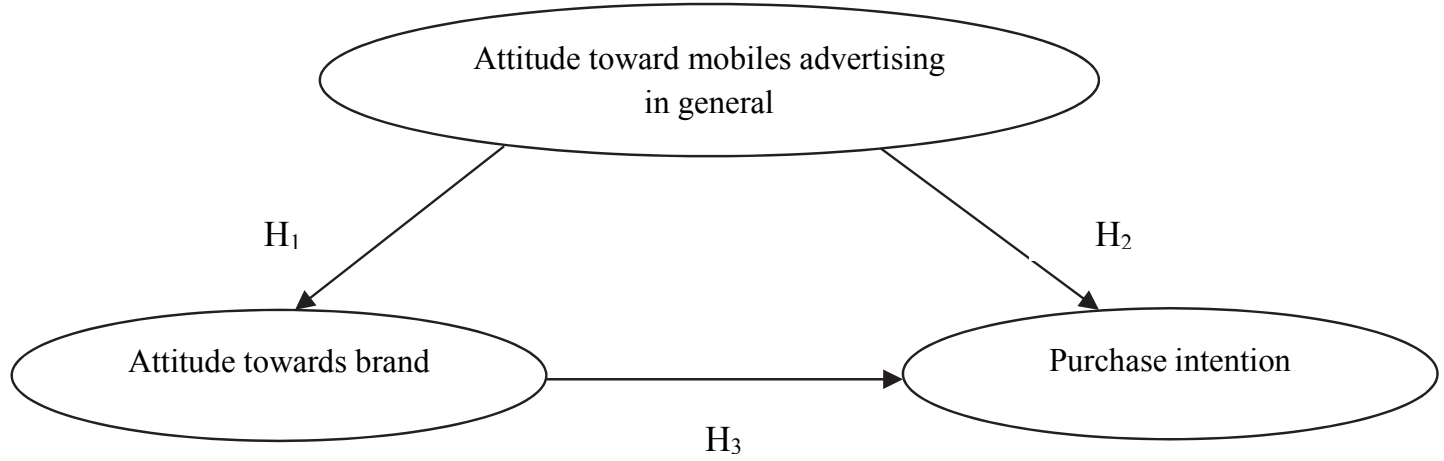

Fig. 1. The conceptual model

\section{Methods}

To test our hypotheses, an experiment was necessary in this study.

\subsection{Brand selection}

We choose a telecommunication provider, namely Ooredoo brand, widely known for its mobile advertising campaigns.

\subsection{Sample}

The sample consists of 150 student of Tlemcen University (Algeria).

\subsection{Scale selection}

Many scales have been developed to measure the attitude toward mobile advertising. We select items from the scales developed by the following authors (Sing \& Vij, 2008; Mehta, 2000).

- The scale of Grossbart et al. (1986) is used to measure Ab with three items.

- PI is measured by the probability scale of Axelrod (1968).

\subsection{Testing measurement models}

At first and in accordance with the Churchill procedure, we conduct principal components analysis with varimax rotation to test the different structures of constructs used in this research, excluding purchase 
intention scale as it consists of a single item. To determine the number of factors to retain, we consider the most usual rule of Kaiser (selected factors corresponding to Eigen values above the unit). Only items with communality greater than 0.5 and the absolute value of their correlation to an axis are greater than 0.6 are retained. Then, the Cronbach's alpha is used to assess the reliability of these constructs. The estimated coefficients can be described as acceptable as they are all above 0.70 . In a second step, we conduct a confirmatory factor analysis with a bootstrap procedure. The validity of each scale is checked by means of absolute, incremental and parsimony indices. In general, all adjustment indices are considered good and acceptable (see Table 1)

\section{Table 1}

Results from Exploratory analyses

\begin{tabular}{|c|c|c|c|c|c|c|c|}
\hline Item & Communalities & $\begin{array}{l}\text { Factor } \\
\text { loading }\end{array}$ & $\%$ explained variance & $\mathrm{KMO}$ & $\begin{array}{l}\text { Bartlett's Test of } \\
\text { Sphericity }\end{array}$ & $\begin{array}{l}\text { Eigen } \\
\text { values }\end{array}$ & $\begin{array}{c}\text { Cronbach } \\
\text { Alpha }\end{array}$ \\
\hline Aad1 & 0,811 & 0,9 & & & & & \\
\hline Aad2 & 0,605 & 0,778 & & & & & \\
\hline Aad4 & 0,526 & 0,629 & 60,39 & 0,514 & $\mathrm{p}=0,000$ & 1,81 & 0,645 \\
\hline $\mathrm{Ab} 1$ & 0,5 & 0,887 & & & & & \\
\hline $\mathrm{Ab} 2$ & 0,787 & 0,803 & & & & & \\
\hline $\mathrm{Ab} 3$ & 0,645 & 0,703 & 64,1 & 0,592 & $\mathrm{p}=0,000$ & 1,92 & 0,702 \\
\hline PI2 & 0,772 & 0,879 & & & & & \\
\hline PI3 & 0,772 & 0,879 & 77,2 & 0,600 & $\mathrm{p}=0,001$ & 1,54 & 0,704 \\
\hline
\end{tabular}

\section{Findings}

To test a causal relationship between a dependent variable and one or more independent variables, it is necessary to use an explanatory analysis. Our model can be tested using a simple and multiple regression model. We chose the regression analysis because it is characterized by its simplicity and can explain a quantitative variable by several other independent quantitative variables.

\subsection{Effect of Aad on $\mathrm{Ab}$}

As Tables (2-4) show, the results obtained postulate that the Aad does not influence the Ab.

Table 2

Summary of models (Relation $\mathrm{Aad} \rightarrow \mathrm{Ab}$ )

\begin{tabular}{lrrrr}
\hline Model & R & R square & Adjusted R square & $\begin{array}{c}\text { Std. error of the } \\
\text { estimation }\end{array}$ \\
\hline 1 & $0,194^{\mathrm{a}}$ & 0,038 & 0,012 & 2,30043
\end{tabular}

a. Predicted value: (Constants), Aad

Table 3

ANOVA $^{\text {b }}($ Relation $\mathrm{Aad} \rightarrow \mathrm{Ab})$

\begin{tabular}{llrrrrr}
\hline Model & & Sum of squares & ddl & Mean of squares & D & Sig. \\
\hline 1 & Regression & 7,879 & 1 & 7,879 & 1,489 & $0,230^{\mathrm{a}}$ \\
& Residual & 201,096 & 38 & 5,292 & & \\
\cline { 2 - 7 } & Total & 208,975 & 39 & &
\end{tabular}

a. Predicted value: (Constants), Aad

b. Dependent Variable : Ab

\section{Table 4}

Coefficients $^{\mathrm{a}}($ Relation Aad $\rightarrow \mathrm{Ab}$ )

\begin{tabular}{|c|c|c|c|c|c|c|}
\hline \multirow[b]{2}{*}{ Model } & & \multicolumn{2}{|c|}{ Unstandardized Coefficients } & $\begin{array}{l}\text { Standardized } \\
\text { Coefficients }\end{array}$ & \multirow[b]{2}{*}{$\mathrm{t}$} & \multirow[b]{2}{*}{ Sig. } \\
\hline & & A & Erreur standard & Bêta & & \\
\hline \multirow[t]{2}{*}{1} & (Constant) & 11,017 & 1,486 & & 7,412 & 0 \\
\hline & Aad & 0,169 & 0,139 & 0,194 & 1,22 & 0,23 \\
\hline
\end{tabular}

a. Dependent Variable : Ab 


\subsection{Effect of Aad on PI}

The results indicate that the relationship (Aad-PI) is not significant (see Table 5, Table 6 and Table 7)

\section{Table 5}

Summary of models (Relation Aad $\rightarrow$ PI)

\begin{tabular}{lcccc}
\hline Model & $\mathrm{R}$ & R square & Adjusted R square & $\begin{array}{c}\text { Std. error of the } \\
\text { estimation }\end{array}$ \\
\hline 1 & $0,055^{\mathrm{a}}$ & 0,003 & $-0,023$ & 2,21859 \\
\hline a. Predicted value: (Constants), Aad & & &
\end{tabular}

\section{Table 6}

ANOVA $^{\mathrm{b}}$ (Relation Aad $\left.\rightarrow \mathrm{PI}\right)$

\begin{tabular}{llccccc}
\hline Model & & Sum of squares & ddl & Mean of squares & D & Sig. \\
\hline \multirow{2}{*}{1} & Regression & 0,558 & 1 & 0,558 & 0,113 & $0,738^{\mathrm{a}}$ \\
& Residual & 187,042 & 38 & 4,922 & & \\
\cline { 2 - 7 } & Total & 187,6 & 39 & & & \\
\hline
\end{tabular}

Table 7

Coefficients(Relation Aad $\rightarrow$ PI)

\begin{tabular}{|c|c|c|c|c|c|c|}
\hline \multirow[b]{2}{*}{ Model } & & \multicolumn{2}{|c|}{ Unstandardized Coefficients } & \multirow{2}{*}{$\begin{array}{c}\begin{array}{c}\text { Standardized } \\
\text { Coefficients }\end{array} \\
\text { Bêta }\end{array}$} & \multirow[b]{2}{*}{$\mathrm{t}$} & \multirow[b]{2}{*}{ Sig. } \\
\hline & & A & Erreur standard & & & \\
\hline \multirow[t]{2}{*}{1} & (Constant) & 6,132 & 1,433 & & 4,278 & 0 \\
\hline & Aad & 0,045 & 0,134 & 0,055 & 0,337 & 0,738 \\
\hline
\end{tabular}

a. Dependent Variable : PI

The results of the hypotheses $\mathrm{H} 1$ and $\mathrm{H} 2$ could be explained by the fact that the Algerian mobile users perceive mobile advertising as intrusive, and have negative perceptions about them.

\subsection{Effect of Ab on PI}

The results show that $\mathrm{Ab}$ influence purchase intention.

Table 8

Summary of models (Relation $\mathrm{Ab} \rightarrow \mathrm{PI}$ )

\begin{tabular}{lrrrr}
\hline Model & R & R square & Adjusted R square & $\begin{array}{c}\text { Std. error of the } \\
\text { estimation }\end{array}$ \\
\hline 1 & $0,502^{\mathrm{a}}$ & 0,252 & 0,232 & 1,92162 \\
\hline a. Predicted value: (Constants), $\mathrm{Ab}$ & & & &
\end{tabular}

Table 9

$\operatorname{ANOVA}^{\mathrm{b}}$ (Relation $\left.\mathrm{Ab} \rightarrow \mathrm{PI}\right)$

\begin{tabular}{llrrrrr}
\hline Model & & Sum of squares & ddl & Mean of squares & D & \multicolumn{1}{c}{ Sig. } \\
\hline 1 & Regression & 47,28 & 1 & 47,28 & 12,804 &, $001^{\text {a }}$ \\
& Residual & 140,32 & 38 & 3,693 & \\
\cline { 2 - 7 } & Total & 187,6 & 39 & & & \\
\hline
\end{tabular}

a. Predicted value: (Constants), Ab

b. Dependent Variable : PI 
Table 10

Coefficients $^{\mathrm{a}}$ (Relation $\left.\mathrm{Ab} \rightarrow \mathrm{PI}\right)$

\begin{tabular}{|c|c|c|c|c|c|c|}
\hline \multirow[b]{2}{*}{ Model } & & \multicolumn{2}{|c|}{ Unstandardised Coefficients } & $\begin{array}{l}\text { Standardised } \\
\text { Coefficients }\end{array}$ & \multirow[b]{2}{*}{$\mathrm{t}$} & \multirow[b]{2}{*}{ Sig. } \\
\hline & & $\mathrm{A}$ & Erreur standard & Bêta & & \\
\hline 1 & (Constant) & 0,524 & 1,725 & & 0,303 & 0,763 \\
\hline & $\mathrm{Ab}$ & 0,476 & 0,133 & 0,502 & 3,578 & 0,001 \\
\hline
\end{tabular}

a. Dependent Variable : PI

\section{Conclusion and discussion}

Experts predict a significant growth of mobile advertising market in the coming years in Algeria that remains largely under-exploited. In fact, it is a perfect tool to establish a closer relationship between the brand and the consumer. Nevertheless, the understanding of the effectiveness of this specific form of communication is still in its infancy. After a short review of the literature on mobile advertising and its effects on consumer attitudes, we tested the influence of attitude towards mobile advertising on the attitudes of the Algerian consumer. The results obtained among a sample of 150 students using a regression analysis, showed firstly, the existence of a direct positive link between Ab and PI, and secondly, confirm our conclusions about the direct role of Ab on IP and support the existing literature. Thus, a consumer who has a positive attitude towards a brand is more likely, for example, first to buy the products offered by this brand, second, to consume again the product and third, recommend it to his friends. Furthermore, the results show that attitude towards mobile advertising has no influence on the attitude toward the brand and purchase intention. One explanation for this may be sought in the work on the intrusiveness of mobile advertising. Researchers agree on the fact that individuals are increasingly anxious to preserve their privacy. Mobile advertising therefore can present several risks of rejection. Hence, the need for a precise segmentation by firms. Brands must also build a relationship with their customers based on loyal clients in order to have permissions to send messages or applications through their mobile.

\section{References}

Allport, G. W. (1935). Attitudes. In C. Murchison (Ed.), Handbook of social psychology. (pp. 798844).

Assael, H. (1984). Consumer behavior and marketing action. Kent Pub. Co..

Bagozzi, R. P. (1981). Attitudes, intentions, and behavior: A test of some key hypotheses. Journal of Personality and Social Psychology, 41(4), 607-627.

Baker, M. J., \& Churchill Jr, G. A. (1977). The impact of physically attractive models on advertising evaluations. Journal of Marketing Research, 14(4), 538-555.

Berger, I. E., \& Alwitt, L. F. (1996). Attitude conviction: a self-reflective measure of attitude strength. Journal of Social Behavior and Personality, 11(3), 555.

Bovee, C. L., \& Arens, W. F. (1994). Contemporary advertising. Irwin Professional Publishing.

Campbell, D. T. (1963). From description to experimentation: Interpreting trends as quasi-experiments.

Davis, F. (1986). Perceived usefulness, perceived ease of use, and user acceptance of information technology. MIS Quarterly, 13(3), 319-339.

Derbaix, C. (1995). L'impact des réactions affectives induites par les messages publicitaires : hune analyse tenant compte de l'implication. Recherche et Applications en Marketing, 10(2), 3-30.

Pecheux, C., \& Derbaix, C. (1999). Children and attitude toward the brand: A new measurement scale. Journal of Advertising Research, 39(4), 19-19.

Doob, L. W. (1947). The behavior of attitudes. Psychological Review, 54(3), 135.

Duhaime, C.P., Kindra, G.S., Laroche, M., \& Muller, TE. (1996). Le comportement du consommateur, Editor Gaétan Morin, 2nd edition, 669. 
Fishbein, M., \& Ajzen, I. (2011). Predicting and changing behavior: The reasoned action approach. Taylor \& Francis.

Greenwald, A. G. (1968). On defining attitude and attitude theory. Psychological Foundations of Attitudes, 361-388.

Grossbart, S., Muehling, D. D., \& Kangun, N. (1986). Verbal and visual references to competition in comparative advertising. Journal of Advertising, 15(1), 10-23.

Hoffman, D. L., \& Novak, T. P. (1996). Marketing in hypermedia computer-mediated environments: Conceptual foundations. The Journal of Marketing, 60(3), 50-68.

Howard, J. A. (1989). Consumer behavior in marketing strategy. Prentice Hall.

Kothandapani, V. (1971). Validation of feeling, belief, and intention to act as three components of attitude and their contribution to prediction of contraceptive behavior. Journal of Personality and Social Psychology, 19(3), 321.

Kotler, P. (2006). Marketing-Management (pp. 20-28). Poeschel.

Krugman, H. E. (1975). What makes advertising effective. Harvard Business Review, 53(2), 96-103.

Lendrevie, J., \& Lévy, J. (2012). Mercator 2013: Théories et nouvelles pratiques du marketing. Dunod.

Li, H. (2004). Responses to mobile advertising: a diary study of mobile phone users. In Proceedings of the conference-American Academy of Advertising (pp. 248-249). Pullman, WA; American Academy of Advertising; 1999.

Lutz, R. J. (1985). Affective and cognitive antecedents of attitude toward the ad: A conceptual framework. Psychological processes and advertising effects, 45-63.

Mehta, A. (2000). Advertising attitudes and advertising effectiveness. Journal of advertising research, 40(3), 67-72.

Merabet. A., \& Benhabib, A. (2014). The moderating role of brand familiarity and product involvement in the relationship between brand personality and persuasive advertising elaboration. European Academic Research, 2(3), 3965-3994.

Merabet, A., \& Benhabib, A. (2012). Brand Personality: Antecedents and Consequences. Indian journal of marketing, 42(10), 11-21.

Myers, J., Aaker, D.A., \& Betra, D. (1996). Advertising Management. Englewood Cliffs, NJ : PrenticeHall).

Ostrom, T. M. (1969). The relationship between the affective, behavioral, and cognitive components of attitude. Journal of Experimental Social Psychology, 5(1), 12-30.

Oliver, R. L. (1980). A cognitive model of the antecedents and consequences of satisfaction decisions. Journal of Marketing Rresearch, 17(4), 460-469.

Petrof, J. V. (1993). Comportement du consommateur et marketing. Presses Université Laval.

Petty, R. E., \& Cacioppo, J. T. (1981). Attitudes and persuasion: Classic and contemporary approaches. Dubuque, IA: Wm. C. Brown.

Petty, R. E., \& Cacioppo, J. T. (1986). Communication and persuasion: Central and peripheral routes to attitude change. New York: SpringerVerlag.

Scharl, A., Dickinger, A., \& Murphy, J. (2005). Diffusion and success factors of mobile marketing. Electronic commerce research and applications, 4(2), 159-173.

Singh, R., \& Vij, S. (2008). Public attitude toward advertising: An empirical study of Northern India. The ICFAI Journal of Marketing Management, 7(1), 49-66.

Yang, K. C. (2005). Exploring factors affecting the adoption of mobile commerce in Singapore. Telematics and informatics, 22(3), 257-277.

www.mmaglobal.com

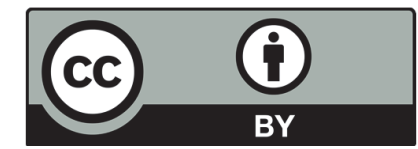

(C) 2017 by the authors; licensee Growing Science, Canada. This is an open access article distributed under the terms and conditions of the Creative Commons Attribution (CC-BY) license (http://creativecommons.org/licenses/by/4.0/). 